\title{
PENGGUNAAN MEDIA GAMBAR DALAM MENINGKATKAN KEAKTIFAN SISWA DALAM PEMBELAJARAN PENGETAHUAN SOSIAL DI SEKOLAH DASAR
}

\begin{abstract}
Nina Sundari ${ }^{1}$
ABSTRAK

Tujuan artikel ini yaitu untuk mengetahui langkah-langkah dalam menggunakan media gambar dalam pembelajaran Pengetahuan Sosial pada siswa Sekolah Dasar dan untuk mengetahui keefektifan penggunaan media gambar dalam pembelajaran Pengetahuan Sosial pada siswa Sekolah Dasar. Dengan menggunakan media gambar pembelajaran Pengetahuan Sosial khususnya pada siswa Sekolah Dasar, dapat diketahui bahwa motivasi belajar siswa menjadi lebih tinggi dalam proses pembelajaran tersebut. Hal ini disebabkan dengan adanya penggunaan media gambar yang membuat siswa lebih tertarik dan bersemangat untuk belajar. Keaktifan dalam kegiatan belajar mengajar terjadi pada kedua belah pihak yaitu guru dan siswa.
\end{abstract}

\section{Kata Kunci: Keaktifan Siswa, Media Gambar, Pengetahuan Sosial}

\section{A. PENDAHULUAN}

Untuk dapat melaksanakan pembelajaran Pengetahuan Sosial dengan baik pada jenjang pendidikan Sekolah Dasar, diperlukan guru yang terampil merancang dan mengelola proses pembelajaran seperti yang tertuang dalam kurikulum tingkat satuan pendidikan (KTSP) 2006. Dalam pelaksanaan kurikulum tersebut guru hendaknya dapat menggunakan strategi yang melibatkan siswa aktif dalam belajar baik secara fisik, mental, maupun sosial. Para guru diharapkan dapat merancang dan mengelola proses pembelajaran dengan menyajikan sebaikbaiknya dan mengatur kondisi yang baik pula. Selain itu pendidikan mengarahkan siswa menjadi subyek yang memiliki kemampuan dan daya serap yang tinggi, kreatif, mandiri dan profesional. Dalam kaitannya dengan pendidikan, Tiller (1997:1 ) mengemukakan bahwa : Pendidikan nasional dewasa ini sedang dihadapkan pada empat krisis pokok, yang berkaitan dengan kuantitas, relevansi atau efesiensi eksternal, elitisme, dan manajemen.

Menghadapi hal tersebut, perlu dilakukan penataan terhadap sistem pendidikan secara menyeluruh, Terutama berkaitan dengan kualitas pendidikan, Serta relevansinya dengan kebutuhan masyarakat dan dunia kerja. Dalam hal ini, Perlu adanya perubahan sosial yang memberi arah bahwa pendidikan merupakan pendekatan dasar dalam proses perubahan itu. Pendidikan adalah (Mulyasa, 2001:7) kehidupan untuk kegiatan belajar harus dapat membekali siswa, kecakapan hidup yang sesuai dengan lingkungan kehidupan dan kebutuhan siswa. Dengan demikian, setiap guru hendaknya secara profesional mampu mengatasi masalah belajar yang dihadapi para siswa, sehingga proses interaksi belajarmengajar dapat berlangsung secara efektif dan efesien serta berdaya guna.

\footnotetext{
${ }^{1}$ Dosen UPI Kampus Cibiru
} 
Pendidikan adalah salah satu hal yang sangat penting untuk membekali siswa menghadapi masa depan. Untuk itu proses pembelajaran yang bermakna sangat menentukan terwujudnya pendidikan yang berkualitas. Siswa perlu mendapat bimbingan, dorongan, dan peluang yang memadai untuk belajar dan mempelajari hal-hal yang akan mereka perlukan dalam kehidupan bermasyarakat. Berdasarkan hasil observasi metode pembelajaran Pengetahuan Sosial di Sekolah Dasar cenderung masih terpusat pada pembelajaran yang menggunakan metode ceramah dalam penyajian materinya. Karena menurut beberapa guru metode ceramah merupakan metode yang paling mudah dilaksanakan oleh setiap guru saat melakukan proses belajar mengajar di kelas. Hal inilah yang menyebabkan banyak siswa menganggap proses pembelajaran Pengetahuan Sosial itu adalah sesuatu yang membosankan, terlalu banyak hafalan, tidak variatif dan berbagai keluhan lainnya. Sebagaimana terdapat dalam Undang - Undang No. 2 tahun 1989 tentang Sistem Pendidikan Nasional, Pasal 35 yang menyatakan Bahwa "Setiap satuan pendidikan jalur pendidikan sekolah, baik yang di selenggarakan oleh pemerintah maupun masyarakat harus menyediakan sumber belajar”. Jadi pendidikan tidak mungkin terselenggara dengan baik apabila para tenaga kependidikan maupun para peserta didik tidak didukung oleh sumber belajar yang diperlukan untuk penyelenggaraan kegiatan belajar mengajar yang bersangkutan.

Mengacu pada fenomena di atas, maka proses pembelajaran Pengetahuan Sosial hendaknya menggunakan sebuah media yang dapat menunjang pembelajaran tersebut, salah satu di antaranya dengan memanfaatkan media pembelajaran. Media pembelajaran tersebut merupakan wahana untuk menyampaikan informasi atau pesan pembelajaran pada siswa, dengan adanya media pada proses belajar-mengajar diharapkan dapat membantu guru dalam meningkatkan pemahaman belajar siswa sehingga proses belajar mengajar dapat berlangsung dengan baik. Melihat hal diatas sebaiknya para guru menghadirkan media dalam setiap proses pembelajaran demi tercapainya tujuan yang hendak dicapai. Sesuai dengan pendapat Hamalik (1994:12) yang menyatakan Bahwa "media pembelajaran adalah alat, metode dan teknik yang digunakan dalam rangka lebih mengefektifkan komunikasi dan interaksi antara guru dan siswa dalam proses pembelajaran dikelasnya”. Oleh karena itu penulis memilih judul penelitian dalam pembelajaran Pengetahuan Sosial dengan menggunakan media gambar agar siswa lebih aktif dalam pembelajaran, dan juga agar siswa tidak merasa bosan saat belajar dengan menghadirkan media gambar yang menarik dalam pembelajaran Pengetahuan Sosial khususnya pada siswa Sekolah Dasar.

Dalam jurnal ini terdapat beberapa permasalahan yang ingin dibahas oleh penulis. Rumusan masalah tersebut yaitu :

1. Bagaimana langkah-langkah dalam menggunakan media gambar denah dalam pembelajaran Pengetahuan Sosial pada siswa Sekolah Dasar?

2. Apakah dengan menggunakan media gambar denah dalam pembelajaran Pengetahuan Sosial dapat meningkatkan keaktifan siswa Sekolah Dasar?

Dalam setiap permasalahan pasti akan terdapat cara-cara untuk memecahkan permasalahan tersebut, begitu juga dalam penelitian ini. Adapun pemecahan masalah pada penelitian ini adalah : 
1. Menjelaskan langkah-langkah dalam penggunaan media gambar denah dalam pembelajaran Pengetahuan Sosial pada siswa Sekolah Dasar

2. Meningkatkan keaktifan siswa dengan menggunakan media gambar pada Pengetahuan Sosial pada siswa Sekolah Dasar

Adapun tujuan yang hendak dicapai dalam penelitian ini adalah :

1. Untuk mengetahui langkah-langkah dalam menggunakan media gambar denah dalam pembelajaran Pengetahuan Sosial pada siswa Sekolah Dasar.

2. Untuk mengetahui keefektifan penggunaan media gambar dalam pembelajaran Pengetahuan Sosial pada siswa Sekolah Dasar

Dengan adanya penelitian ini hasil diharapkan memberikan kontribusi bagi dunia pendidikan khususnya dalam bidang Pengetahuan Sosial pada siswa di Sekolah Dasar. Manfaat dari hasil penelitian ini dapat dijelaskan sebagai berikut :

1. Bagi guru dengan dilaksanakannya penelitian ini di harapkan guru dapat mengetahui peningkatan kualitas siswa dalam pembelajaran Pengetahuan Sosial pada siswa di Sekolah Dasar dengan menggunakan media gambar.

2. Sebagai bahan masukan kepada pengemban pendidikan mengenai pemberdayaan media gambar dalam meningkatkan keaktifan siswa sekolah dasar dalam mempelajari Pengetahuan Sosial.

3. Diharapkan dari hasil penelitian ini dapat memberikan andil tersendiri dalam pengembangan khasanah keilmuan khususnya Pengetahuan Sosial pada sekolah dasar.

\section{B. LANDASAN TEORI}

Di antara beberapa media pembelajaran media gambar adalah di antara media pembelajaran, media gambar adalah media yang paling umum dipakai. Hal ini dikarenakan siswa lebih menyukai gambar daripada tulisan, apalagi jika gambarnya dibuat dan disajikan sesuai dengan persyaratan gambar yang baik, sudah barang tentu akan menambah semangat siswa dalam mengikuti proses pembelajaran. Di bawah ini beberapa pengertian media gambar, diantaranya:

1. Media gambar adalah segala sesuatu yang diwujudkan secara visual kedalam bentuk dua dimensi sebagai curahan ataupun pikiran yang bentuknya bermacam-macam seperti lukisan, potret, slide, film, strip, opaque projektor (Hamalik, 1994:95).

2. Media gambar adalah media yang paling umum dipakai, yang merupakan bahasan umum yang dapat dimengerti dan dinikmati dimana-mana (Sadiman, 1996:29).

3. Media gambar merupakan peniruan dari benda-benda dan pemandangan dalam hal bentuk, rupa, serta ukurannya relatif terhadap lingkungan (Soelarko, 1980:3).

Dari pengertian di atas dapat disimpulkan bahwa media gambar adalah perwujudan lambang dari hasil peniruan-peniruan benda-benda, pemandangan, curahan pikir atau ide-ide yang di visualisasikan kedalam bentuk dua dimensi. Pemanfaatan media pembelajaran ada dalam komponen metode mengajarsebagai salah satu upaya untuk mempertinggi proses interaksi guru-siswa dan interaksi siswa dengan lingkungan belajarnya. Oleh sebab itu fungsi utama dari media pembelajaran adalah sebagai alat bantu mengajar, yakni menunjang penggunaan 
metode mengajar yang dipergunakan guru. Melalui penggunaan media pembelajaran diharapkan dapat mempertinggi kualitas proses belajar-mengajar yang pada akhirnya dapat mempengaruhi kualitas hasil belajar siswa. Secara garis besar, fungsi penggunaan media gambar adalah sebagai berikut :

1. Fungsi edukatif, yang artinya mendidik dan memberikan pengaruh positif pada pendidikan.

2. Fungsi sosial, memberikan informasi yang autentik dan pengalaman berbagai bidang kehidupan dan memberikan konsep yang sama kepada setiap orang.

3. Fungsi ekonomis, meningkatkan produksi melalui pembinaan prestasi kerja secara maksimal.

4. Fungsi politis, berpengaruh pada politik pembangunan.

5. Fungsi seni budaya dan telekomunikasi, yang mendorong dan menimbulkan ciptaan baru, termasuk pola usaha penciptaan teknologi kemediaan yang modern (Hamalik, 1994:12).

Fungsi-fungsi tersebut di atas terkesan masih bersifat konseptual. Fungsi praktis yang dijalankan oleh media pengajaran adalah

1. Mengatasi perbedaan pengalaman pribadi peserta didik, misalnya kaset video rekaman kehidupan di laut sangat diperlukan oleh anak yang tinggal di daerah pegunungan.

2. Mengatasi batas ruang dan kelas. Misalnya gambar tokoh pahlawan yang dipajang di ruang kelas.

3. Mengatasi keterbatasan kemampuan indera.

4. Mengatasi peristiwa alam. Misalnya rekaman peristiwa letusan gunung merapi untuk menerangkan gejala alam.

5. Menyederhanakan kompleksitas materi.

6. Memungkinkan siswa mengadakan kontak langsung dengan masyarakat atau alam sekitar (Rohani, 1997:6-7).

Setiap media yang digunakan dalam metode pembelajaran memiliki kelebihan yang dapat memperlancar proses belajar mengajar, begitu juga dengan media gambar yang memiliki beberapa kelebihan seperti yang dikemukakan oleh (Sadiman,1996:31). Kelebihan media gambar tersebut yaitu

1. Sifatnya konkret dan lebih realistis dalam memunculkan pokok masalah, jika dibandingkan dengan bahasa verbal.

2. Dapat mengatasi batasan ruang dan waktu.

3. Dapat mengatasi keterbatasan pengamatan kita.

4. Memperjelas masalah dalam bidang apa saja dan untuk semua orang tanpa memandang umur sehingga dapat mencegah atau membetulkan kesalahpahaman.

5. Harganya murah dan mudah didapat serta digunakan

Keefektifan media gambar yang digunakan dalam proses belajar mengajar tersebut sebagai upaya dalam membina pengetahuan, sikap, dan keterampilan para siswa melalui interaksi siswa dengan lingkungan belajar yang diatur guru. Pada hakikatnya pembelajaran ini mempelajari lambang-lambang verbal dan visual, agar diperoleh makna yang terkandung di dalamnya. Lambang-lambang tersebut dicerna, disimak oleh para siswa sebagai penerima pesan yang disampaikan guru. Oleh karena itu pengajaran dikatakan efektif apabila siswa dapat memahami 
makna yang dipesankan oleh guru sebagai pemberi pesan. Pesan visual yang paling sederhana, praktis, mudah dibuat dan banyak diminati siswa pada jenjang pendidikan dasar adalah gambar. Menurut Sudjana (200:12) tentang bagaimana siswa belajar melalui gambar adalah sebagai berikut :

1. Ilustrasi gambar merupakan perangkat pengajaran yang dapat menarik minat belajar siswa secara efektif.

2. Ilustrasi gambar merupakan perangkat tingkat abstrak yang dapat ditafsirkan berdasarkan pengalaman di masa lalu, melalui penafsiran kata- kata.

3. Ilustrasi gambar membantu para siswa membaca buku pelajaran terutama dalam menafsirkan dan mengingat-ingat isi materi teks yang menyertainya.

4. Dalam booklet, pada umumnya anak-anak lebih menyukai setengah atau satu halaman penuh bergambar, disertai beberapa petunjuk yang jelas.

5. Ilustrasi gambar isinya harus dikaitkan dengan kehidupan nyata, agar minat para siswa menjadi efektif.

6. Ilustrasi gambar isinya hendaknya ditata sedemikian rupa sehingga tidak bertentangan dengan gerakan mata pengamat, dan bagian-bagian yang paling penting dari ilustrasi itu harus dipusatkan di bagian sebelah kiri atas media gambar.

Dengan demikian media gambar merupakan salah satu teknik media pembelajaran yang efektif karena mengombinasikan fakta dan gagasan secara jelas, kuat dan terpadu melalui pengungkapan kata-kata dan gambar.

\section{PEMBAHASAN}

\section{Manfaat Media Gambar dalam pembelajaran Pengetahuan Sosial}

Media pembelajaran Pengetahuan Sosial di Sekolah Dasar khususya pada media gambar merupakan alat bantu yang dapat digunakan untuk menghantarkan ataupun menyampaikan pesan berupa ilmu pengetahuan kepada para siswa agar tujuan pembelajaran dapat tercapai. Secara umum manfaat media gambar di Sekolah Dasar pada pembelajaran Pengetahuan Sosial yaitu :

a. Sebagai alat bantu untuk mewujudkan situasi kemajuan yang efektif.

b. Bagian integral dari keseluruhan mengajar.

c. Meletakkan dasar-dasar yang kuat dan konsep yang abstrak sehingga dapat mempunyai pemahaman yang bersifat verbalisme.

d. Membangkitkan motivasi belajar siswa.

e. Mempertinggi hasil dan mutu belajar mengajar.

\section{Langkah-langkah penggunaan media gambar}

Langkah-langkah pembelajaran Pengetahuan Sosial pada siswa Sekolah Dasar menggunakan media gambar yaitu sebagai berikut :

a. Menyiapkan media gambar yang akan digunakan untuk memberikan materi Pengetahuan Sosial kepada para siswa sekolah Dasar. Para guru harus benarbenar memahami pembelajaran yang akan diberikan kepada para siswa dan memiliki berbagai macam strategi yang akan digunakan dalam penyampaian materi kepada para siswa. 
b. Siswa di perkenalkan dengan strategi pembelajaran yang dipakai dan diperkenalkan dengan media gambar, kemudian siswa diminta untuk mencermati media gambar tersebut dengan cara mereka sendiri namun tetap dalam pengawasan guru.

c. Dalam proses pembelajaran siswa mencoba berbagai strategi untuk menyelesaikan masalah sesuai dengan pengamatanya. Hal ini dapat dilakukan secara peroraangan, dengan mengerjakan LKS yang di berikan oleh guru untuk dinilainyadan media gambar sebagai obyek penelitiannya.

d. Setelah mencapai kesepakatan tentang srategi dalam mengerjakan LKS diarahkan untuk menarik kesimpulan dari pelajaran tersebut. Pada akhir pembelajaran siswa harus dapat menjelaskan pengetahuan apa saja yang mereka dapatkan dari pembelajaran Pengetahuan Sosial yang dijalankan menggunakan media gambar tersebut didepan guru dan teman-teman kelasnya. Hal ini dapat menjadi tolak ukur kesuksesan penyampaian materi pembelajaran dengan media gambar dan penilaian keaktifan siswa dalam belajar.

\section{Keaktifan Siswa}

Proses belajar mengajar merupakan kegiatan interaksi antara guru dengan murid untuk mencapai tujuan yang diinginkan dalam pembelajaran tersebut, artinya bahwa pembelajaran yang di laksanakan dalam pembelajaran tersebut harus dapat mengarahkan peserta didik kepada pencapaian suatu kompetensi yang diinginkan secara aktif. John Dewey dalam (Uzer, 2001:78 ), sebagai tokoh pendidikan,mengemukakan pentingnya prinsip ini melalui metode proyeknya dengan semboyan learning by doing. Mengajar adalah proses interaksi siswa dalam kegiatan belajar mengajar, dengan demikian aktivitas siswa sangat diperlukan dalam kegiatan belajar mengajar di bangku sekolah.

Kondisi belajar mengajar yang efektif adalah minat dan perhatian siswa dalam belajar, Uzer (2001) mengemukakan bahwa "minat ini besar sekali pengaruhnya terhadap belajar sebab dengan minat seseorang akan melakukan sesuatu yang diminatinya, sebaliknya tanpa minat seseorang tidak mungkin melakukan sesuatu”. Keterlibatan siswa dalam belajar erat kaitanya dengan sifatsifat murid, baik yang bersifat kognitif seperti kecerdasan dan bakat, maupun yang bersifat keaktifan, rasa percaya diri dan minatnya. Minat dalam arti motif adalah daya dalam diri seseorang yang mendorongnya untuk melakukan sesuatu, atau keadaan seseorang atau organisme yang menyebabkan kesiapannya untuk memakai serangkaian tingkah laku atau perbuatan. Sedangkan keaktifan adalah suatu proses untuk menggiatkan motif - motif menjadi perbuatan atau tingkah laku untuk memenuhi kebutuhan dan mencapai tujuan atau keadaan atau kesiapan dalam diri individu yang mendorong tingkah lakunya untuk berbuat sesuatu dalam mencapai tujuan tertentu. Tugas guru adalah membangkitkan keaktifan anak sehingga ada keinginannya untuk belajar. Keaktifan dapat timbul dari dalam diri individu dan dapat pula timbul akibat pengaruh dari luar dirinya. (Inrakusuma, 1981:87 ). Proses belajar mengajar yang menyenangkan terjadi apabila siswa sendiri yang aktif dalam pembelajaran dalam hal keterlibatan intelektual emosional siswa dalam kegiatan belajar mengajar yang bersangkutan, asimilasi 
dan akomodasi kognitif dalam pencapaian pengetahuan perbuatan serta pengalaman langsung terhadap baliknya (feedback) dalam pembentukan keterampilan dan penghayatan serta internalisasi nilai-nilai dalam pembentukan sikap.

\section{KESIMPULAN}

Berdasarkan hasil pembelajaran Pengetahuan Sosial dengan menggunakan media gambar khususnya pada siswa Sekolah Dasar, dapat diketahui bahwa motivasi belajar siswa lebih tinggi dalam proses pembelajaran menggunakan media gambar tersebut. Hal ini disebabkan dengan adanya penggunaan media gambar yang membuat siswa lebih tertarik dan bersemangat untuk belajar. Keaktifan siswa lebih meningkat di mana siswa merasa lebih dapat berekspresi dalam belajar sehingga para siswa aktif dalam kegiatan belajar mengajar di kelas, bukan hanya guru saja yang aktif dalam pembelajaran ini. Para siswa juga dapat menyadari apa tujuan yang hendak dicapai dari pembelajaran tersebut dan menyadari manfaat apa yang diperoleh bagi dirinya.

Motivasi siswa dengan sendirinya muncul kuat dan tertanam dalam dirinya. Mereka ingin menguasai kemampuan yang terkandung dalam tujuan pembelajaran yang bermanfaat untuk dirinya, sehingga menghasilkan pemahaman pembelajaran Pengetahuan Sosial yang lebih mendalam, kritis, dan kreatif. Nilai yang dicapai para siswapun mengalami peningkatan dari yang rendah menjadi lebih baik setelah melakukan pembelajaran Pengetahuan Sosial dengan penggunaan media gambar ini.

\section{DAFTAR PUSTAKA}

Depdikbud, 2006. Kurikulum Pendidikan Dasar . Jakarta : Proyek peningkatan Mutu SD, TK, dan SLB.

Hamalik, 1994. Media Pendidikan . Bandung : Citra Aditya Bakti.

Indarakusuma, Amir Dien.1981. Ilmu Pendidikan. Surabaya : Usaha Nasional

Mulyasa, 2001. Kurikulum Berbasis Kompetensi, Jakarta : Remaja Karya.

Rohani, Ahmad. 1997. Media Instruksional Edukatif. Jakarta : Rineka Cipta

Sadiman, Arif. 1996. Media Pendidikan .Jakarta : Raja Grafindo Persada

Soelarko. 1980. Psikologi pendidikan, Jakarta : Depdikbud

Sudjana. 2001. Media Pengajaran. Bandung: Sinar Baru Algensindo

Tilaar, HAR.1997. Pengembangan Sumber Daya Manusia dalam Era Globalisasi. Jakarta : Grasindo

Uzer, Usman.2001. 2001. Menjadi Guru Profesional. Bandung : Remaja Rosda Karya 